\title{
Author Correction: METTL3 promotes tumour development by decreasing APC expression mediated by APC mRNA $N^{6}$-methyladenosine- dependent YTHDF binding
}

Wei Wang (1), Fei Shao, Xueying Yang, Juhong Wang, Rongxuan Zhu, Yannan Yang, Gaoxiang Zhao, Dong Guo, Yingli Sun, Jie Wang, Qi Xue, Shugeng Gao, Yibo Gao (1), Jie He \& Zhimin Lu (1)

Correction to: Nature Communications https:/doi.org/10.1038/s41467-021-23501-5, published online 21 June 2021

The original version of this Article contained an error in the author's affiliations.

The affiliation of Zhimin Lu with the Department of Thoracic Surgery, National Cancer Center/National Clinical Research Center for Cancer/Cancer Hospital, Chinese Academy of Medical Sciences and Peking Union Medical College, Beijing, China, was inadvertently omitted.

This has now been corrected in both the PDF and HTML versions of the Article.

Published online: 20 July 2021

Open Access This article is licensed under a Creative Commons Attribution 4.0 International License, which permits use, sharing, adaptation, distribution and reproduction in any medium or format, as long as you give appropriate credit to the original author(s) and the source, provide a link to the Creative Commons license,
and indicate if changes were made. The images or other third party material in this article are included in the article's Creative Commons license, unless indicated otherwise in a credit line to the material. If material is not included in the article's Creative Commons license and your intended use is not permitted by statutory regulation or exceeds the permitted use, you will need to obtain permission directly from the copyright holder. To view a copy of this license, visit http://creativecommons.org/licenses/by/4.0/.

(c) The Author(s) 2021 